\title{
ARTI DAN MAKNA KEBENARAN ILMIAH DALAM TELAAH HUKUM ISLAM
}

\author{
Ahmad Gazali HB \\ Fakultas Syariah dan Ekonomi Islam IAIN Antasari, Jl. Jenderal Ahmad Yani Km 4,5 Banjarmasin \\ e-mail:aghazali.iain@gmail.com
}

\begin{abstract}
This writing is the description about the scientific truth of the Islamic Law, or in the Islamic science treasury is called Fiqh. Through the scientific process, we can find out lots theories of truths, for instant the correspondent, coherent, pragmatic, syntactic, semantic, non descriptive and over logic truth. Toward those theories of truth, there are three approach methodologies that we can apply to get them. The first methodology is the religious approach, the second one is the scientific approach, and the last one is the philosophic approach. These three approach methodologies are closely relates with the development of the Islamic Law, since they are also the scientific disciplines. In the Islamic Law, there is also mention about the correspondence and coherence truth. The methodology that is used to result the laws related to the general scientific methodology as well. For that reason, the truth which is resulted from that scientific approach is mostly positive.
\end{abstract}

Abstrak: Tulisan ini adalah paparan mengenai kebenaran ilmiah dalam konteks suatu ilmu yang dalam tulisan ini adalah Hukum Islam, atau dalam istilah khazanah keilmuan Islam disebut dengan "Fiqh". Dalam proses ilmiah, ternyata beragam kebenaran yang dapat diketahui antara lain: kebenaran korespondensi, koherensi, pragmatis, sintaksis, semantis, non deskripsi dan logis yang berlebihan. Terhadap teori-teori kebenaran tersebut ada tiga pendekatan yang dilakukan untuk mendapatkannya. Pertama: pendekatan Agama, kedua: Pendekatan Ilmu Pengetahuan, ketiga: Pendekatan Filosofis. Ketiga pendekatan ini sangat erat dengan pengembangan Hukum Islam. Karena merupakan suatu disiplin ilmu pengetahuan.Hukum Islam juga memuat kebenaran-kebenaran di atas, terutama kebenaran korespendensi dan kebenaran koherensi. Metodologi yang dipakai dalam upaya menemukan norma hukum juga terkait dengan metode ilmiah pada umumnya. Oleh karena itu kebenran yang dihasilkan secara ilmiah tersebut, menjadi kebenaran yang relatif positif.

Kata kunci: Arti dan makna, kebenaran ilmiah, bukum islam, macam-macam.

\section{Pendahuluan}

Hukum Islam merupakan bagian integral dari ajaran Islam yang merefleksi secara menyeluruh ciri-ciri ajaran Islam. Dengan demikian Hukum Islam akan menampilkan diri sebagai suatu sistem hukum yang mandiri di samping sistem hukum lainnya yang ada di dunia.

Dalam konsepsi pemikiran (Islam), aspek hukum ditempatkan secara lebih menonjol bila dibandingkan dengan aspek-aspek lainnya. H.A.R Gibb menyatakan "it is characterristic of the practical trand of the Islamic community of it's thought that it's earlist activity and most highly developed expression is in law rather than theology" (H.A.R. Gibb, 1953: 87).

Menurut hakikatnya, agama Islam adalah suatu agama yang sudah disempurnakan (Al Qur'an: 5:3) sehingga mempunyai ruang lingkup yang mencakup semua aspek kehidupan manusia baik pribadi maupun interpribadi. Terhadap keseluruhan aspek ajaran Islam, umat Islam diperintahkan untuk tunduk dan taat dan harus menerima ajaran sebagai suatu sistem yang utuh dan bulat (Al Qur'an 2: 208). Dari sini kemudian muncul anggapan bahwa apapun yang terkait dengan label "Islam" lalu harus dianggap mutlak dalam kebenarannya. Padahal banyak diantaranya yang dihasilkan melalui proses metodologi keilmuan (Ijtihad), termasuk diantaranya Fiqh atau Hukum Islam yang lahir melalui proses ijtihad dengan metodologi ilmu Fiqh (Ushul alFiqh).

Seringkali orang memahami bahwa Hukum Islam adalah sabda-sabda suci yang sama sekali tidak boleh dipersoalkan dalam kerangka ilmiah. Padahal bila ditelaah secara kritis akan segera diketahui bahwa Hukum Islam sebagaimana sistem-sistem hukum lainnya, hadir dalam upaya memecahkan persoalan-persoalan yuridis dalam masyarakat (Nizam al-Din Abu Hamid, 1984: 910). Demikian pula kehadiran metodologi Hukum Islam atau yang dikenal dengan istilah "Ushul Fiqh" (produknya adalah Fiqh) 
seharusnya dipahami sebagai hasil pergumulan pemikiran ilmiah (Mun’im A. Sirry, 1955: 80).

Oleh karena itu membicarakan Hukum Islam (Fiqh) tidak akan terlepas dari pembicaraan Ushul Fiqh sebagai metodologinya dan bila berbicara tentang metodologi, kita akan berbicara tentang suatu disiplin ilmu dan kebenaran ilmiah.

Kajian semacam ini membawa satu titik pandangan yang agak relevan dengan kajian kebenaran ilmiah dalam perspektif perkembangan ilmu pengetahuan, terutama dalam perspektif ilmu Hukum Islam.

\section{Kebenaran Ilmiah Teori Kebenaran}

Dalam perkembangan pemikiran filsafat pembicaraan mengenai kebenaran sudah ada sejak masa Plato dan Aristoteles. Perbincangan tentang kebenaran ini diawali oleh kebenaran manusia sebagai makhluk yang berpikir. Dalam Ilmu Mantiq disebut bahwa: AL-INSANU HAYAWANU NATIQUN (Manusia itu adalah makhluk yang berpikir). Aristoteles (384-322 SM) mengatakan: man as the animal that reasons (Endang saifuddin, A. 1979: 14), demikian juga Rene Descartes (1596-1650) berpendirian: Cogito ergo sum (Harun Hadiwijono, 1997: 21).

Bila manusia adalah makhluk yang berpikir dan berpikir adalah bertanya, bertanya adalah mencari jawaban, maka mencari jawaban adalah mencari kebenaran. Jadi manusia adalah makhluk rasional yang mempergunakan otaknya untuk berpikir secara rasional, dan dari hasil pemikiran yang rasional itulah kebenaran bisa didapat. Karena itu pada dasarnya manusia adalah makhluk pencari kebenaran (Endang saifuddin, A., 1979: 16).

Untuk menjawab apa kebenaran itu ? Ada beberapa teori tentang kebenaran (The Theory of Trutb). Teori-teori kebenaran yang telah berkembang adalah:

1. Teori kebenaran Korespondensi.

2. Teori kebenaran Koherensi.

3. Teori kebenaran Pragmatis.

4. Teori kebenaran Sintaksis.

5. Teori kebenaran Semantis.

6. Teori kebenaran Non-Deskripsi.

7. Teori kebenaran Logis yang berlebihan (Abbas Hamami, 1997: 87).]

\section{Teori Kebenaran Korespondensi.}

Kebenaran Korespondensi adalah berpikir tentang pembuktian sesuatu itu relevan dengan sesuatu yang lain. Relevansi tersebut dibuktikan dengan adanya peristiwa yang sejalan atau berlawanan arah antar fakta yang diharapkan, anatara fakta dengan kepercayaan yang diyakini, yang sifatnya spesifik (Phenomonologi Russell).

The Correspondence Theory of Truth dinamakan juga dengan The Accordence Theory of Truth, bahwa suatu persyaratan itu benar bila meteri pengetahuan yang dikandung itu berhubungan dengan objek yang dituju oleh pernyataan tersebut. Contoh: "Ibu Kota R.I. adalah Jakarta".

Pernyataan ini benar, karena pernyataan itu berhubungan dengan objek yang bersifat faktual. Jadi kebenaran menurut teori korespondensi ialah kesesuaian antara pernyataan tentang sesuatu dengan sesuatu itu sendiri. Bila kenyataannya memang "Ibu Kota R.I. adalah Jakarta", maka pernyataan itu adalah suatu kebenaran (Endang Saifuddin A., 1979: 20).

\section{Teori Kebenaran Koherensi.}

Suatu yang koheren dengan sesuatu yang lain berarti ada kesesuaian atau keharmonisan dengan sesuatu yang memiliki hirarki yang lebih tinggi. Pemilik hirarki yang lebih tinggi dari sesuatu unsur tersebut dapat berupa skema, sistem, atau nilai. Koherensi ini mungkin saja pada dataran sensual rasional atau pada dataran transenden (Noeng Muhadjir, 1998: 14). Secara sederhana teori kebenaran koherensi adalah kebenaran saling berhubungan menurut Kattsoff dalam bukunya Element of Philosophy mengatakan; Suatu proposisi cenderung benar jika proposisi tersebut dalam keadaan saling berhubungan dengan proposisi-proposisi lain yang benar, atau jika makna yang dikandungnya dalam keadaan saling berhubungan dengan pengalaman kita (Soejono Soemargono, 1987: 184). The Coherence Theory of Truth, menyatakan bahwa suatu pernyataan dianggap benar bila pernyataan itu saling berhubungan atau cocok dengan pernyataan sebelumnya yang dianggap benar.

Contoh: Semua manusia pasti akan mati $=\mathrm{A}-\mathrm{B}$

Ahmad adalah seorang manusia $=\mathrm{C}-\mathrm{A}$

Ahmad pasti mati $=\mathrm{C}-\mathrm{B}$.

Tokoh teori ini adalah Plato dan Aristoteles (Yuyun S. Suria Sumantri, 1995: 55-57) yang kemudian dikembangkan oleh Hagel dan F. H. Bradley. 
Teori Kebenaran Pragmatis (The Pragmatic Theory of Truth)

Menyatakan bahwa yang benar adalah konkret, yang individual dan spesifik. J. Dewey melanjutkan bahwa kebenaran merupakan korespondensi antara ide dengan fakta, dan arti korespondensi menurut Dewey adalah kegunaan praktis (Noeng Mahadjir, 1998: 16). Dengan demikian suatu pernyataan adalah benar bila pernyataan itu non konsekuensi, dari pernyataan itu mempuyai kegunaan praktis dalam kehidupan manusia.

Bagi seorang pragmatis kebenaran suatu pernyataan diukur dengan kriteria apakah pernyataan tersebut bersifat fungsional dalam kehidupan praktis, artinya suatu pernyataan adalah benar bila pernyataan itu atau konsekuensi dari pernyataan itu mempuyai kegunaan praktis dalam kehidupan manusia. Dan kreteria pragmatisme dipergunakan dalam menentukan kebenaran dilihat dalam perspektif waktu, maka pernyataan yang sekarang dianggap benar suatu waktu mungkin tidak benar lagi.

Jadi selama pernyataan itu mempuyai kegunaan, maka pernyataan itu dianggap benar. Tetapi bila pernyataan itu tidak bersifat demikian karena perkembangan yang menghasilkan pernyataan baru, maka pernyataan itu ditinggalkan. Seperti pendapat di kalangan ahli Fisika bahwa teori tentang partikel takkan berumur lebih dari empat tahun (Yuyun S. Suria Sumantri, 1995; 57-59). Sama artinya suatu pengertian itu tidak pernah benar, tetapi hanya dapat menjadi benar kalau bermamfaat secara praktis.

Pragmatisme (bahasa Yunani; pragma berarti yang dikerjakan, yang dilakukan, perbuatan, tindakan/suatu istilah bagi filsafat yang dikembangkan oleh William James di Amerika Serikat, yang menyatakan bahwa benar tidaknya suatu ucapan, dalil atau teori semata-mata bergantung kepada berfaedah tidaknya ucapan, dalil atau teori tersebut bagi manusia untuk bertindak dalam kehidupannya. Dan pandangan pragmatisme tentang Tuhan ialah bahwa suatu agama bukan benar karena Tuhan yang disembah oleh para penganut agama itu sungguh-sungguh ada, tetapi karena pengaruhnya yang positif atas kehidupan manusia; berkat kepercayaan orang akan Tuhan, maka kehidupan masyarakat berlaku secara tertib (Endang Saifuddin A, 1979: 25-28).

\section{Teori Kebenaran Sintaksis}

Teori ini bertitik tolak kepada keteraturan sintaksis atau gramatika yang dipakai oleh suatu pernyataan. Artinya suatu pernyataan benar jika pernyataan itu mengikuti aturan-aturan sintaksis yang baku (Abbas Hamami, 1987; 88)

\section{Teori Kebenaran Semantis}

Menurut teori kebenaran semantik, suatu proposisi memiliki nilai benar ditinjau dari segi arti atau makna, atau dengan kata lain bahwa proposisi baru mempuyai nilai kebenaran jika ia memiliki arti. Arti ini akan menunjukkan makna yang sesungguhnya bila disandarkan pada referensi atau kenyataan.

\section{Teori Kebenaran Non-Deskripsi}

Suatu pernyataan itu akan mempuyai nilai benar akan sangat tergantung pada peran dan fungsi pernyataan tersebut. Artinya sesuatu itu benar bila memang dapat diaktualkan dalam tindakan kehidupan sehari-hari.

\section{Teori Kebenaran Logis yang Berlebihan (Logical Superfluity of Truth)}

Teori yang dikembangkan aliran Positivistik ini pada dasarnya menyatakan kebenaran itu proposisi yang merupakan fakta atau data yang telah memiliki evidensi. Artinya objek pengetahuan itu telah menunjukkan kejelasan dalam dirinya sendiri. Seperti pernyataan bahwa lingkaran itu bulat. Pernyataan itu telah menunjukkan kejelasan yang tidak perlu diterangkan lagi.

\section{Kebenaran Ilmiah}

Horold H. Titus menyatakan bahwa, kebenaran ialah sesuatu yang sesuai dengan fakta atau sesuatu yang selaras dengan situasi aktual. Kebenaran ialah kesesuaian (agreement) antara pernyataan (statement) mengenai fakta dengan fakta aktual atau antara keputusan (judgement) dengan situasi di seputar (environmental situatioan) yang diberikan interpretasi (Miska Muhammad Amien, 1983: 8).

Kebenaran pada awalnya berada dalam diri si pengenal. Kebenaran diberi batasan sebagai kesesuaian akal dengan kenyataan yang terjadi pada tarap pengalaman inderawi maupun akal budi, tanpa pernah sampai pada kesamaan yang sempurna yang dituju kebenaran dalam pengalaman manusia. Dalam ilmu pengetahuan kebenaran selalu bersifat sementara/relatif (C. Verhaak \& Haryono, 1989: 133-134). Kebenaran ilmiah lahir pada proses penelitian ilmiah. Ia harus melalui prosedur yang baku dengan tahapan-tahapan tertentu, yang disebut dengan 
istilah metodologi sesuai dengan objek yang dihadapi.

Kebenaran dalam ilmu pengetahuan adalah kebenaran yang sifatnya objektif, yakni kebenaran yang harus didukung oleh fakta-fakta, kenyataan dalam objektivannya. Kebenaran tersebut harus lepas dari keinginan subjek.

Secara antologis, pada dasarnya kebenaran ilmu pengetahuan digolongkan kepada dua jenis teori yaitu teori kebenaran korespondensi untuk ilmu-ilmu kealaman dan teori kebenaran koherensi, untuk ilmu-ilmu humaniora dan sosial. Sifat kebenaran ilmu adalah universal sejauh kebenaran tersebut dapat dipertahankan, oleh karena itu kebenaran ilmu akan diakui bila mampu melewati proses eliminasi terhadap kemungkinan kekeliruan dan kesalahan (C. Verhaak \& Haryono, 1989: 160).

Dari wacana yang berkembang menyangkut masalah kebenaran dapat diambil garis penghubung bahwa kebenaran ilmu pengetahuan adalah kesesuaian antara subjek yang mengetahui dengan objek yang diketahui, Bertran Russell mengatakan: "Kebenaran adalah suatu sifat kepercayaan, dan diturunkan dari kalimat yang menyatakan kepercayaan itu" (Yuyun S. Suria Sumantri, 1981: 76).

\section{Hukum Islam \\ Hukum Islam (Fiqh) Sebagai Sebuah Fenomena}

Hukum Islam merupakan suatu fenomena yang bertalian erat sekali dengan perkembangan yang terjadi pada masa silam, A. A. Fyzee menyatakan bahwa: "Hukum Islam sebagaimana yang kita kenal dewasa ini adalah hasil suatu proses perkembangan yang terus menerus selama tersiarnya Islam dalam masa empat belas abad" (A. A. Fyzee, 1955: 1-2).

Tahap awal dari perkembangan Hukum Islam adalah di zaman Rasul Saw dan Khulafatu alRasyidin dalam fase dimana Hukum Islam dilaksanakan secara benar dan tuntas sehingga terbina suatu "Islamic Community" sebagaimana yang dikehendaki oleh Allah Swt dalam Qur'an. Akan tetapi perkembangan politik pada masa itu telah membelokkan arah perkembangan yang menyimpang dari prinsip-prinsip kebenaran Hukum Islam. Walaupun demikian masih ada pendapat yang mengatakan dan menganggap bahwa masa ini sebenarnya belum ada apa yang dinamakan "Hukum Islam", menurut para ahli, Hukum Islam itu baru lahir menjelang akhir abad pertama hijrah bersamaan dengan lahirnya mazhab-mazhab Fiqh dalam dunia Islam. Pendapat-pendapat yang demikian mucul karena ada yang menyamakan antara syari'ah (Hukumhukum yang langsung ada dalam Qur'an) dengan Figh. Dan melihat kaidah-kaidah hukum (Fiqh) adalah ditemukan dalam karya-karya para Fukaha (ahli Fiqh).

Timbulnya pandangan yang menyamakan antara Syari'ah dengan Fiqh telah melahirkan pandangan yang keliru tentang Hukum Islam. Salah satu pandangan yang menyesatkan dikemukakan oleh Prof. Snouck Hurgronje yang menyatakan: "Bukannya Al Qur'an yang memberikan pengertian tentang Islam kepada kita, akan tetapi kitab-kitab hukum, (Fiqh) dan teologi yang ada semenjak abad ke III hijrah" (H. M. Rasyidi, 1968: 15).

Pandangan ini juga ternyata banyak mempengaruhi para ahli hukum Indonesia yang mempelajari Hukum Islam dari sumber Barat.

Fase kedua dari perkembangan Hukum Islam merupakan studi intensif tentang hukum (Islam) dengan timbulnya apa yang dinamakan "Ilmu Fiqh" sebagai sarana penunjangnya. Di masa inilah lahirnya para pemikir hukum Islam (Mujtahid) yang telah memperkembangkan prinsip-prinsip hukum yang termuat dalam al Qur'an dan Sunnah melalui ijtihad, sehingga terbentuk berbagai ajaran Hukum Islam yang mengelompokkan diri dalam berbagai mazhab Fiqh. Dalam fase ini banyak ditulis interpretasi hukum secara kontekstual (dari Al Qur'an dan Sunnah) yang tetap dipergunakan hingga kini.

\section{Hukum Islam (Fiqh Al Islam) Sebagai Suatu Disiplin Ilmu}

Sebagaimana disebutkan di dalam perbidangan ilmu agama Islam, Hukum Islam (Fiqh) merupakan salah satu disiplin ilmu.

Arti hukum secara mutlak "menetapkan sesuatu atas sesuatu atau menafikannya". Jika menetapkan atau menafikannya itu melalui jalan akal, seperti barang yang berlawanan tidak bisa berkumpul, maka ia adalah Hukum Akli (Akal/Rasio). Jika menafikan atau menetapkan itu melalui sarana adat naluri, seperti api itu biasanya membakar, ia adalah Hukum Adat (kebiasaan) atau Empiris Apriori. Dan jika menetapkan atau menafikannya itu melalui jalan Syara' (Agama Islam) seperti shalat itu wajib dan meminum khamar itu haram (dilarang), maka ia adalah Hukum syar'i. Inilah yang dikatakan Hukum Syara' (Syari'ah) yakni hukum yang telah ada di dalam Al Qur'an, yang mengatur 
perbuatan-perbuatan manusia yang lahir maupun yang batin dan sifat-sifat Syar'i itu menjadi sandaran bagi para Fukaha untuk menetapkan hukum atau menafikan sesuatu seperti: wajib, haram, makruh, mubah maupun sunat (Ali Hasballah, 1964: 2-3). Dengan demikian sebanarnya Hukum Islam (Fiqh) itu merupakan bagian dari syari'ah.

Ibrahim Husen mengatakan bahwa Fiqh itu Hukum Islam yang bersifat zhanni (relatif), yang ditegaskan secara langsung atau tidak oleh nash Al Qur'an dan Sunnah (Hadits) dan ia baru diketahui setelah digali oleh pemikiran/ijtihad (Ibrahim Husen, 1981: 7).

Menurut Fukaha, Hukum Islam (Fiqh) itu ialah ilmu yang berhubungan dengan hukumhukum Syar'i yang amali (Practical) yang diambil dari dalil-dalilnya yang tafsili (terinci), atau ilmu tentang hukum-hukum Syar'i yang tertentu bagi perbuatan-perbuatan para mukallaf/manusia yang berakal (M. Yusuf Musa, 1956: 9). Sedangkan "Ulama Ushul Fiqh" mengatakan bahwa Hukum Islam itu adalah Khittah (Titah) Allah Swt yang berhubungan dengan perbuatan para mukallaf, baik ia mengandung tuntutan (suruhan atau larangan) atau menerangkan pilihan (boleh pilih antara melakukan atau tidak melakukan) maupun merupakan Wada' (menjadikan sesuatu itu sebab, syarat atau penghalang hukum) (Muh. Abu. Zahrah, 1973: $26 \& 69)$.

Sebagai suatu ilmu, Hukum Islam merupakan hasil kegiatan berpikir berdasarkan pandangan tertentu dalam usaha untuk menganalisa, membahas, dan mencari cara pemecahan masalah-masalah yang terdapat dalam masyarakat dalam kaitannya dengan kehidupan manusia sebagai warga masyarakat. Hal ini disebut sebagai hasil "istimbat" (mengeluarkan dari sumbernya melalui ijtihad untuk menetapkan atau menafikan hukum) yang memerlukan penalaran.

Kegiatan berpikir ini dilakukan dengan jalan mencurahkan segala kemampuan berpikir untuk mengeluarkan Hukum Islam dari prinsip Syar'i yang bersumber dari Al Qur'an dan Sunnah. Dan kegiatan berpikir ini dilakukan oleh para ahli Hukum Islam pada suatu waktu dan tempat, hasilnya adalah pendapat-pendapat mereka sebagai hasil pemikirannya yang tidak lepas dari pengaruh waktu dan tempat serta adat kebiasaan dan lingkungan sosial budaya hidupnya (Muh. Hudari Bek, 1985: 5). Hasil pemikiran yang berbeda-beda satu dengan yang lain itulah yang terkelompok dalam mazhab-mazhab Fiqh atau dikenal dengan aliran-aliran Hukum Islam.

Dalam kepustakaan tentang Hukum Islam di dunia Barat dikenal dua terminologi, yaitu Islamic Jurisprudence sebagai terjemahan Fiqh (Hukum Islam) yang diartikan sebagai hasil pemahaman para ahli Hukum Islam klasik terhadap Syari'ah dan Hukum Islam (Fiqh) diakui sebagai disiplin ilmu (Funk \& Wagnalls, 1963: 735).

\section{Ushul Al Fiqh Sebagai Filsafat Hukum Islam.}

Salah satu landasan untuk menempatkan Hukum Islam sebagai salah satu sistem hukum di antara berbagai sistem hukum di dunia dan diakui sebagai suatu disiplin ilmu, harus ada kejelasan tentang bagaimana filsafat hukumnya. Apakah Hukum Islam mempuyai filsafatnya sendiri? Persoalan ini kurang begitu mendapat perhatian dikalangan para fukaha, terutama setelah Al Gazali menyatakan penolakan terhadap filsafat. Pengabaian terhadap aspek filsafat ini dalam kajian Hukum Islam, menimbulkan kesan bahwa Hukum Islam tidak menpunyai filsafat hukumnya sendiri.

Pandangan ini baru ditolak setelah terbitnya beberapa karya tulis yang membahas filsafat Hukum Islam seperti Dr. Sobhi Mahmasani dengan "Filsafat al Tasyri Fi al Islam", Muhammad Khalid Mas'ud dengan karyanya "Islamic Legal Philosophy" dan Prof. T. M. Hasby ash Shidiqy dengan "Filsafat Hukum Islam"nya.

Para ahli kemudian sepakat menyebutkan bahwa Ushul al Fiqh sebagai Filsafat Hukum Islam. Pemikiran kefilsafatan ini muncul dalam sistem kajian Hukum Islam pada abad II H dari era perkembangan Hukum Islam dengan Imam Asy Syafi'i sebagai konseptornya dengan karyanya "Ar Risalah". Dengan karya inilah lahir metode pengambilan Hukum Islam dan juga metode penerapannya.

Filsafat Hukum Islam ialah filsafat yang diterapkan pada Hukum Islam, dan ia merupakan filsafat khusus. Perbedaan antara Filsafat dengan Filsafat Hukum Islam terletak pada objeknya. Filsafat meneliti segala sesuatu, sedangkan Filsafat Hukum Islam hanya meneliti Hukum Islam (O. Notohamidjojo, 1975: 9). Filsafat Hukum Islam merupakan bagian dari filsafat Islam yang dapat dianggap bahwa filsafat Hukum Islam merupakan anak sulung dari Filsafat Islam. 
Filsafat Hukum Islam menganalisa secara metodis dan sistematis sehingga mendapatkan keterangan yang mendasar tentang Hukum Islam. Filsafat Hukum Islam menganalisa Hukum Islam secara ilmiah dengan menggunakan filsafat sebagai alatnya (Philosophical Approach), sistematis dapat dipertanggungjawabkan dan radikal tentang Hukum Islam (Ahmad Azhar Basyir, 1984: 4).

Sesuai dengan watak filsafat, filsafat Hukum Islam berusaha menjawab pertanyaan-pertanyaan fundamental secara logik-rasional dan bertanggung jawab. Pertanggungjawaban secara rasional pada hakikatnya bahwa langkah harus terbuka terhadap segala pertanyaan dan sanggahan dan harus mempertahankan secara argumentatif dengan landasan yang objektif yang dapat dimengerti secara intersubjektif. Pada hakikatnya filsafat Hukum Islam bersikap kritis terhadap persoalan-persoalan hukum, dalam arti bahwa ia tak pernah puas diri, tidak menganggap bahwa suatu jawaban itu sudah final, tetapi selalu bersedia untuk membuka perdebatan atau diskursus-diskursus ilmiah.

Metode berpikir tersebut dinamakan metode kritis atau dialektis, yaitu kritik yang berulangulang dan yang teliti tentang pendapat-pendapat. Metode dialektis adalah suatu percobaan untuk bersikap adil terhadap pendirian-pendirian yang bertentangan, tidak dengan menghargai pendirian itu menurut cara yang kaku, tetapi dengan bertanya dalam menghadapi setiap problema, apakah akibat-akibat problema-problema itu. Sesuatu pendirian mungkin kelihatannya baik dan masuk akal, tetapi bila kita teliti secara mendalam kadang terdapat paradoks-paradoks. Cara yang baik adalah dengan menunjukkan bahwa sesuatu itu salah ialah dengan cara dialektis yang membawa kepada Self-Contradiction dengan dirinya sendiri (H. M. Rasyidi, 1970: 12-13).

\section{Mencapai Kebenaran}

Pada hakikatnya manusia adalah makhluk yang cenderung untuk mencari kebanaran. Dalam wacana dan perspektif filsafat pengetahuan, ada tiga metode pendekatan yang dapat digunakan untuk mencari kebenaran yaitu pendekatan agama, pendekatan ilmu pengetahuan, dan pendekatan filsafat. Dengan pendekatanpendekatan tersebut manusia akan menemukan kebenaran Agama (Religious Truth), kebenaran Ilmiah (Scientific Truth) dan kebenaran Filsafat (Philosophycal Truth).

\section{Kebenaran Agama}

Agama adalah tata aturan ilahi untuk mereka yang berakal, yang mau mempercayainya. Agama Islam adalah agama yang diwahyukan oleh Allah Swt, kepada RasulNya Muhammad Saw untuk disampaikan kepada seluruh manusia guna menjadi petunjuk kehidupan mereka.

Dengan pengertian yang seperti itu, maka unsur pokok agama adalah Tuhan YME, Rasul dan Kitab Suci. Dalam agama Islam Allah Swt yang memberi wahyu, Rasul Muhammad Saw yang menerima wahyu dan Kitab Suci Al Qur'an yang diwahyukan. Dengan demikian sumber utama ajaran agama Islam adalah Al Qur'an.

Al Qur'an ialah kalam Allah yang diturunkan untuk manusia umat Nabi Muhammad dengan bahasa Arab. Tafsiran atau terjamahan ke dalam bahasa apapun tidak dapat lagi dinamakan $\mathrm{Al}$ Qur'an (Muh. Salam Madkur, 1964: 70). Oleh karena itu nilai kebenarannya tidak mesti mutlak, karena ia merupakan hasil pemikiran manusia seperti pada firman Allah Swt:

1. Dirikanlah Shalat (Q.S. 2: 43).

2. Atau kamu telah menyentuh perempuan (Q. S. 4: 43).

Pemikiran terhadap ayat pertama menghasilkan kesimpulan bahwa "Shalat" itu "wajib". Dan kesimpulan ini diakui oleh seluruh umat Islam sebagai suatu kesimpulan yang benar. Kesimpulan yang benar ini adalah suatu kebenaran yang kebenarannya diakui oleh seluruh orang Islam (disepakati oleh seluruh umat Islam). Maka kebenaran kesimpulan bahwa "Shalat" itu "wajib" adalah kebenaran mutlak (Absolute Truth).

Pemikiran terhadap ayat kedua menghasilkan kesimpulan:

a. Sentuhan dengan perempuan itu membatalkan wudlu' dan

b. Sentuhan dengan perempuan itu tidak membatalkan wudhu'.

Perbedaan kesimpulan tersebut disebabkan: 1) kesimpulan pertama mengartikan bahwa "sentuhan" itu sentuhan biasa, maka sentuhan "biasa" membatalkan wudhu', 2) kesimpulan kedua mengartikan "sentuhan" itu bermakna hubungan badan/persetubuhan, maka sentuhan "biasa" dengan perempuan tidak membatalkan wudhu'.

Kedua kesimpulan tersebut dianggap benar dan merupakan kebenaran, tetapi karena adanya perbedaan pemikiran sehingga menghasilkan kesimpulan yang berbeda, maka kedua kesimpulan tersebut menjadi kebenaran relatif (Relative 
Truth). Dalam perspektif ilmu ia bisa saja disebut dengan kebenaran korespondensi.

\section{Kebenaran Ilmu Pengetahuan}

Ilmu pengetahuan pada hakikatnya merupakan segenap apa yang kita ketahui tentang suatu objek tertentu, termasuk di dalamnya ilmu pengetahuan itu sendiri. Dan ilmu pengetahuan merupakan khazanah kekayaan mental yang turut memperkaya kehidupan manusia.

Kiranya sulit dibayang bagaimana kehidupan manusia tanpa ilmu pengetahuan, karena ia sumber jawaban bagi berbagai pertanyaan yang muncul dalam kehidupan. Dan pada dasarnya setiap jenis ilmu pengetahuan menjawab pertanyaan tertentu, maka perlu diketahui jawaban apa yang dapat diberikan oleh ilmu pengetahuan tertentu atau perlu diketahui kepada pengetahuan mana pertanyaan itu diajukan (Yuyun S. Suria Sumantri, 1995: 104-105).

Kita boleh mengajukan pertanyaan kepada siapa saja, tetapi pada hakikatnya kita mengharapkan jawaban yang benar. Dan yang menjadi tujuan ilmu pengetahuan ialah tercapainya kebenaran. Untuk mencapai tujuan itu, yakni kebenaran, perlu menempuh cara yang dikenal dengan metode ilmiah (Endang Saifuddin A., 1979: 57). Dan cara yang dilalui oleh proses ilmu pengetahuan sehingga mencapai kebenaran menurut Cogoci-hypotheticoverifikasi adalah:

1. Perumusan masalah;

2. Penyusunan kerangka berpikir dalam mengajukan hipotesis;

3. Perumusan hipotesis;

4. Pengujian hipotesis;

5. Penarikan kesimpulan. (Yuyun S. Suria Sumantri, 1995: 127-128).

Dengan demikian ilmu pengetahuan tersusun secara konsisten dan kebenarannya teruji secara empiris. Proses pembuktian dalam ilmu tidak bersifat absolut, karena ilmu tidak bertujuan mencari kebanaran absolut, tetapi kebenaran yang bermanfaat bagi manusia. Dalam setiap perkembangan selanjutnya kemungkinan tidak benar sangat terbuka. Oleh karena itu kebenaran itu adalah positif pada waktunya sekaligus relatif.

\section{Kebenaran Filsafat}

Berpikir filsafati adalah berpikir sistematis dan logis dalam rangka mendapatkan kesimpulan yang dianggap benar, sehingga dianggap benar. Berpikir filsafati adalah berpikir yang menggunakan logika sebagai alatnya sehingga kesimpulannya logis dan benar (H. A. Chotib, 1990: 22).
Logika adalah suatu sistem untuk dapat mencapai kesimpulan yang benar, dan mengenai penalaran proposional logika simbolik telah menciptakan metode tabe kebenaran (Truth Table). Setiap proposisi menyatakan sesuatu dan apa yang dinyatakan itu adalah benar atau salah, maka setiap proposisi mempuyai nilai benar atau salah. Adapun kebanaran proposisi majemuk ditentukan oleh kebenaran dan kesalahan proposisi anggotanya. Kebenaran dan kesalahan proposisi majemuk dan proposisi anggotanya tergantung pada perakit yang digunakan, yakni perakit "dan" dan perakit "atau" (R. G. Soekardijo, 1983: 72). Tabel kebenaran adalah:

1. Konjungsi (Conjunction): adalah hubungan antara satu proposisi dengan proposisi lain dengan perakit "dan" yang diberi simbol "A". Dikatakan bahwa satu konjungsi hanya benar apabila kedua proposisi anggotanya benar, selain itu salah seperti " $A$ " dihubungkan dengan proposisi " $B$ " dengan perakit "dan" sebagai berikut:

\begin{tabular}{|c|c|c|}
\hline A & B & A \\
& V B \\
\hline B & B & B \\
\hline B & S & S \\
\hline S & B & S \\
\hline S & S & \\
\hline
\end{tabular}

Aplikasinya pada $\mathrm{Al}$ qur'an: (Q. S. 4: 34)

"Kaum laki-laki adalah pemimpin bagi kaum perempuan, oleh karena Allah telah melebihkan sebagian laiki-laki atas sebagian perempuan "dan" karena mereka (laki-laki) itu telah menafkahkan sebagian harta mereka".

Ayat tersebut adalah proposisi mejemuk yang menggunakan perakit "dan", oleh karena itu konjungsi kebenarannya ditentukan oleh kebenaran dan kesalahan proposisi anggotanya. Proposisi majemuk hanya benar apabila kedua anggotanya benar, selain itu salah yaitu apabila salah satu keduanya (proposisi) anggotanya salah. Jadi laki-laki itu pemimpin bagi kaum perempuan hanya benar apabila Allah telah melebihkan sebagian mereka atas sebagian yang lain adalah benar "dan" apabila mereka telah menafkahkan sebagian dari harta mereka adalah benar, selain itu salah (H. A. Chotib, 1990:22-24).

2. Disjungsi (Disjunction) ialah hubungan antara satu proposisi dengan proposisi lain 
dengan perakit "atau" yang diberi simbol "V" dalam wacana ini "atau" tidak selalu sama artinya, tetapi bisa berupa "disjungsi ekslusif" dan bisa "disjungsi inklusif". Pada disjungsi ekslusif salah satu proposisi dari proposisi majemuk mesti benar, tidak kedua-duanya. Tetapi pada disjungsi inklusif, tidak hanya salah satu mesti benar tetapi mungkin juga kedua-duanya benar. Dan konsensus dalam logika ialah bahwa tanda "V" itu adalah lambang disjungsi inklusif (R. G. Soekardijo, 1983: 69-70). Maka kalau dikatakan bahwa suatu proposisi dihubungkan dengan proposisi lain dengan disjungsi adalah benar kalau setidak-tidaknya salah satu dari anggotaanggotanya benar. Misalnya proposisi A dihubungkan dengan proposisi $\mathrm{B}$ dengan perakit "atau" yang diberi simbol "V" seperti pada tabel berikut:

\begin{tabular}{|c|c|c|}
\hline A & B & $\begin{array}{c}\text { A V } \\
\text { B }\end{array}$ \\
\hline B & B & B \\
\hline B & S & B \\
\hline S & B & B \\
\hline S & S & \\
\hline
\end{tabular}

Tabel tersebut adalah tabel kebenaran disjungsi. Aplikasinya (dalam perspektif ilmu) adalah pada ayat (Q. S. 2: 184).

"Maka jika di antara kamu ada yang sakit "atau dalam perjalanan/musafir (lalu ia berbuka dari puasanya), maka wajib baginya berpuasa sebanyak hari yang ditinggalkan itu pada hari-hari yang lain".

Ayat tersebut adalah proposisi majemuk yang menggunakan perakit "atau" yang diberi simbol "V", maka ayat tersebut adalah disjungsi yang kebenarannya ditentukan oleh kebenaran dan kesalahan proposisi anggotanya. Maka proposisi majemuk tersbut adalah benar kalau dan hanya kalau setidak-tidaknya salah satu dari anggotanya benar. Dan karena proposisi majemuk tersebut adalah disjungsi inklusif maka ia benar juga kalau kedua-dua anggotanya benar.

Wacana kebenaran itu dalam Fiqh (Hukum Islam) adalah dalam rangka istimbat Ahkam (pengeluaran hukumhukum yang rasional dan benar secara ilmiah) untuk umat manusia.
Jadi, boleh berbuka puasa itu benar kalau salah satu dari sakit atau dalam perjalanan adalah benar atau kedua-duanya, sakit dan dalam perjalanan adalah benar. Boleh berbuka puasa itu salah kalau keduaduanya, sakit dan dalam perjalanan adalah salah, kendatipun kebenaran tersebut ditemukan secara logis dan ilmiah, kebenaran tersebut tetap relatif (H.A Chotib, 1989: 7).

Artinya kemungkinan makna lain terhadap sakit dan dalam perjalanan secara substantif bisa saja terjadi kemudian. Seperti sakit yang bagaimana dan perjalanan yang bagaimana yang dapat membolehkan berbuka puasa. Apalagi kedua proposisi tersebut sangat rentan terhadap teknologi modern.

\section{Kesimpulan}

Pada dasarnya setiap proses ilmiah akan memunculkan suatu bentuk kebenaran sebagai esensi suatu ilmu pengetahuan. Dan setiap kebenaran memerlukan sarana penguji agar kebenaran tersebut dapat dibuktikan secara metodologis, kendatipun kebanaran itu sendiri bersifat relatif dan sekaligus positif.

Hukum Islam, sebagai suatu disiplin ilmu dalam ruang lingkup ilmu-ilmu Agama Islam, juga tidak bisa lepas dari kaidah-kaidah ilmiah dalam perkembangannya, karena hasil pengembangan itu sendiri telah memuat unsur pemikiran (ijtihad) dan menjadi keniscayaan bahwa kebenaran yang dihasilkan berada dalam koridor kebenaran ilmiah. Hanya saja harus ada pemahaman, mana Hukum Syari'ah dan mana Hukum Figh (al-Islami). Sebagai bagian dari dunia ilmu pengetahuan, Hukum Islam tentu akan terus berkembang sesuai perkembangan teknologi, ilmu pengetahuan dan sosial budaya dimana manusia terlibat di dalamnya.

Kajian-kajian Hukum Islam dengan cakrawala luas sangat diperlukan. Untuk itu filsafat Hukum Islam memegang kunci pemecahan masalahmasalah Hukum Islam yang akan diterapkan dalam masyarakat. Oleh karena itu peran ilmuan akan sangat membantu pengembangan Hukum Islam.

\section{Daftar Rujukan}

Achmad Chotib, H., Pemikiran Filsafat Dalam Hukum Islam, IAIN SYAHID, Jakarta, 1990. 
Achmad Chotib, H., Arti Filsafat Hukum Islam Bagi Abli Hukum Islam, IAIN SYAHID, Jakarta, 1998.

Ahmad Azhar Basyir, Pokok-Pokok Persoalan Filsafat Hukum Islam, Fakultas Hukum UII, Yogyakarta, 1984.

Ali Hasballah, Ushulu al-Tasyri’i al-Islami, Daru alMa'arif, Kairo, 1969.

Abbas Hamami, Kebenaran Ilmiah, dalam Koento Wibisono c.s., Filsafat Ilmu, Intan Pariwara, LP3 UGM, Yogyakarta, 1997.

A. A. Fyzee, Outlines of Mubammadan Law, Oxford University Press, London, 1955.

C. Verhaak \& R. Haryono Imam, Filsafat Ilmu Pengetabuan, Gramedia, Jakarta, 1989.

Endang Saifuddin Anshari, H., Ilmu Filsafat dan Agama, Bina Ilmu, Surabaya. 1979.

Funk \& Wagnalls, Standard College Dictionary, Longmans Canada Ltd, Toronto, 1963.

Harun Hadiwijono, Sari Sejarah Filsafat Barat 2, Kanisius, Yogyakarta, 1997.

H. A. R. Gibb, Muhammadenism, American of World Leterature, 1953.

Ibrahim Husen, Kerangka Landasan Pemikiran Islam Dalam Mimbar Ulama, Jakarta Th IX, 1981.

M. Rasyidi, H., Islam dan Indonesia Di Zaman Modern, Bulan Bintang, Jakarta, 1968.
M. Rasyidi, H., Filsafat Agama, Bulang Bintang, Jakarta, 1970.

M. Salim Madkur, Madkhal al-Fighi al-Islami, Al Maktabah Al-Arabiyah, Kairo, 1964.

M. Yusuf Musa, Al-Fiqhu al-Islami, Darul Kutub al-Hadisah, Kairo, 1956.

M. Hudari Bok, Tarikhu al-Tasyri’i al-Islami, Darul Kutub al-Ilmiyah, Kairo, 1985.

M. Abu Zahrah, Ushulu al-Figh, Darul Fikri alArabi, kairo, 1973.

Miske Muhammad Amien, Epistemologi Islam, UI Press, Jakarta, 1983.

Mun'im A. Sirry, Sejarah Fikib Islam, Risalah Gusti, Surabaya, 1955.

Nizam al-Din Abu Hamid, Mafbum al-Figh alIslami, Muassasah al-Risalah, Bairut, 1984.

Noeng Muhadjir, H., Filsafat Ilmu, Rake Sarasin, Yogyakarta, 1998.

Notohamidjojo, O., Soal-Soal Pokok Filsafat Hukum, BPK Gunung Mulia, Jakarta, 1975.

R. G. Soekardijo, Logika Dasar Tradisional Simbolik dan Induktif, Gramedia, Jakarta, 1983.

Soejono Soemargono, Pengantar Filsafat, Terj, Tiara Wacana, Yogyakarta, 1987.

Yuyun S. Suria Sumantri, Filsafat Ilmu, Pustaka Sinar Harapan, Jakarta, 1995.

Yuyun S. Suria Sumantri, Ilmu Dalam Perspektif, Gramedia, Jakarta, 1987. 